\begin{tabular}{|l|l|l||}
\hline \multicolumn{2}{|c|}{ PublisherInfo } \\
\hline \hline PublisherName & $:$ & BioMed Central \\
\hline \hline PublisherLocation & $:$ & London \\
\hline \hline PublisherImprintName & $:$ & BioMed Central \\
\hline \hline
\end{tabular}

\title{
A large look at lipids
}

\begin{tabular}{|l|l|l||}
\hline \multicolumn{2}{|c|}{ ArticleInfo } \\
\hline \hline ArticleID & $:$ & 4829 \\
\hline \hline ArticleDOI & $:$ & $10.1186 /$ gb-spotlight-20030818-01 \\
\hline \hline ArticleCitationID & $:$ & spotlight-20030818-01 \\
\hline \hline ArticleSequenceNumber & $:$ & 181 \\
\hline \hline ArticleCategory & $:$ & Research news \\
\hline ArticleFirstPage & $:$ & 1 \\
\hline \hline ArticleLastPage & $:$ & 3 \\
\hline \hline & & RegistrationDate : 2003-8-18 \\
\hline ArticleHistory & $:$ & OnlineDate \\
\hline \hline ArticleCopyright & $:$ & BioMed Central Ltd2003-8-18 \\
\hline \hline ArticleGrants & $:$ & \\
\hline \hline ArticleContext & $:$ & 130594411 \\
\hline \hline
\end{tabular}


DNA and proteins have had their day, but lipids are now the molecules du jour. Research into these cellular fats and oils got a big boost last week when the National Institute of General Medical Sciences (NIGMS), part of the National Institutes of Health (NIH), announced a 5-year, \$35-million grant to fund the Lipid Metabolites and Pathways Strategy (LIPID MAPS) Consortium, a large collaborative effort to analyze the structure and function of lipids.

The consortium is led by the University of California, San Diego (UCSD), and comprises more than 30 researchers at 18 US universities, medical research institutes, and companies. This is a major step in the emerging field of metabolomics, or the study of metabolites, said Edward Dennis, a UCSD biochemist and principal investigator of the LIPID MAPS Consortium. In its first year, the project will receive $\$ 6.3$ million from NIGMS.

"Today's large, complex biomedical problems demand more intellectual and physical resources than a single laboratory or small group of laboratories can offer," said NIH Director Elias Zerhouni in a statement last week. "By funding scientists from diverse fields and bringing them together, we expect to significantly improve our understanding of the role of lipids in many serious diseases."

"Lipids are in many ways the most important of the biomolecules because they are the ultimate controllers and regulators of our bodily processes," Dennis told us. "They are key to signaling events in cells." Further, imbalances in lipids are implicated in many illnesses, such as heart disease, stroke, arthritis, diabetes, and Alzheimer disease. "If we are going to solve these diseases, we must know what [the lipids] are and what they do," he added.

The initial studies will seek to identify and measure the amounts of all lipids within a cell - essentially a mapping project. The chosen cell is the macrophage, a key player in the immune response that is also associated with the formation of atherosclerosis plaques in heart disease. The study will provide a better understanding of how lipids interact with one another and with other molecules and structures inside the cell. What we learn from the macrophage mapping, explained Dennis, will be directly applicable to other cells since all cells contain an abundance of lipids. "The LIPID MAPS project will provide the prototype for all other cells," he said.

Ultimately, the project should lead to better drug design and generate new tools and technologies for cataloging and measuring the changing levels of the more than 1000 different lipids in any given cell.

According to Dennis, the biggest challenge will be coordinating the work so that identical protocols are used in the ten core and five bridge projects in the various institutions, thus ensuring that all of the resulting data can be integrated into a consistent picture. Once the information is gathered, all experimental results and protocols will be available through a public Web site. 


\section{References}

1. Wilson JF: Long-suffering lipids gain respect The Scientist, 17:34, March 10, 2003., [http://www.thescientist.com/yr2003/mar/lcprofile_030310.html]

2. LIPID MAPS: Participating Institutions and Researchers, [http:/www.nigms.nih.gov/news/releases/ lipids-participants.html]

3. Lipid Metabolites and Pathways Strategy, [http://www.lipidmaps.org/]

This PDF file was created after publication. 